\title{
PENINGKATAN KEMAMPUAN MENGHAFAL BACAAN - BACAAN SHALAT DENGAN MENGGUNAKAN METODE DRILL DI AWAL PELAJARAN PADA SISWA KELAS 7 SMP NEGERI 1 BANJAR MARGO KABUPATEN TULANG BAWANG
}

\author{
Oleh. \\ Masnah \\ SMP Negeri 1 Banjar Margo Kabupaten Tulang Bawang \\ masnahsumbogo274@gmail.com
}

\begin{abstract}
Learning PAI in class VII of SMP Negeri 1 Banjar Margo is still lacking. In this shortage it is not because the teacher does not master the material, but does not know how to deliver the material properly and correctly, and the teacher does not use the teaching aids or media well in the student environment. Therefore the authors conducted Classroom Action Research (CAR) with the results of discussing the activeness of students in the first cycle who got a score of 5\%, score $b=30 \%$, score $c=65 \%$. Learning outcomes $M$ KKM, which gets a score of $=0 \%$, score $b=27 \%$, score $c=17 \%$. Portfolio data that gets a score of $=3 \%$, score $b=40 \%$, score $c=57 \%$. 2nd meeting, learning activeness which got a score $=7 \%, b$ score $=37 \%, c$ score $=56 \%$. Learning outcomes $M$ KKM, which gets a score of $=0 \%$, score $b=27 \%$, score $c=27 \%$. Portfolio data that gets a score $=10 \%$, score $b=43 \%$, score $c=47 \%$. Cycle II, 3rd meeting, learning activeness which got a score $=23 \%$, score $b=45 \%$, score $c=32 \%$. Learning outcomes $M K K M$, which gets a score of $=23 \%$, score $b=47 \%$, score $c=23 \%$. Portfolio data that gets a score of $=30 \%$, score $b=47 \%$, score $c=23 \%$. 4th meeting, learning activeness which got a score $=30 \%$, score $b=53 \%$, score $c=$ $17 \%$. Learning outcomes $\geq K K M$, which gets a score $=50 \%$, score $b=40 \%$, score $c=10 \%$. Portfolio data that gets a score of $=40 \%$, score $b=47 \%$, score $c$ $=13 \%$. These three aspects have increased.
\end{abstract}

Keywords: improvement, memorizing ability of obligatory prayer readings.

\begin{abstract}
Abstrak
Pembelajaran PAI di kelas VII SMP Negeri 1 Banjar Margo masih kurang. Dalam kekurangan ini bukan karena guru tidak menguasai materi, tetapi tidak tahu bagaimana menyampaikan materi dengan benar, dan guru tidak menggunakan alat bantu mengajar atau media dengan baik di lingkungan siswa. Oleh karena itu penulis melakukan Penelitian Tindakan Kelas (PTK) dengan hasil membahas keaktifan siswa pada siklus I yang mendapat skor $5 \%$, skor $\mathrm{b}=30 \%$, skor $\mathrm{c}=$ $65 \%$. Hasil belajar M KKM, yang mendapat skor $=0 \%$, skor $\mathrm{b}=27 \%$, skor $\mathrm{c}=$ $17 \%$. Data portofolio yang mendapat skor $=3 \%$, skor $\mathrm{b}=40 \%$, skor $\mathrm{c}=57 \%$. Pertemuan ke-2, keaktifan belajar yang mendapat skor $=7 \%$, skor $\mathrm{b}=37 \%$, skor $\mathrm{c}$ $=56 \%$. Hasil belajar M KKM, yang mendapat skor $=0 \%$, skor $\mathrm{b}=27 \%$, skor $\mathrm{c}=$ $27 \%$. Data portofolio yang mendapat skor $=10 \%$, skor $b=43 \%$, skor $\mathrm{c}=47 \%$.
\end{abstract}


Siklus II, pertemuan ke-3, keaktifan belajar yang mendapat skor $=23 \%$, skor $\mathrm{b}=$ $45 \%$, skor $\mathrm{c}=32 \%$. Hasil belajar M KKM, yang mendapat skor $=23 \%$, skor $\mathrm{b}=$ $47 \%$, skor $\mathrm{c}=23 \%$. Data portofolio yang mendapat skor $=30 \%$, skor $\mathrm{b}=47 \%$, skor $\mathrm{c}=23 \%$. Pertemuan ke 4 , keaktifan belajar yang mendapat skor $=30 \%$, skor $\mathrm{b}=53 \%$, skor $\mathrm{c}=17 \%$. Hasil belajar $\geq \mathrm{KKM}$, yang mendapat skor $=50 \%$, skor $\mathrm{b}$ $=40 \%$, skor $\mathrm{c}=10 \%$. Data portofolio yang mendapat skor $=40 \%$, skor $\mathrm{b}=47 \%$, skor $\mathrm{c}=13 \%$. Ketiga aspek ini telah meningkat.

\section{Kata kunci: peningkatan, kemampuan menghafal bacaan doa wajib.}

\section{A. PENDAHULUAN}

Sekolah sebagai salah satu lembaga yang menyelenggarakan pendidikan formal mempunyai peranan yang sangat penting dalam usaha mendewasakan anak didik dan menjadikan anak didik sebagai anggota masyarakat yang paripurna. Sekolah turut pula bertanggung jawab atas anggota masyarakat yang di hasilkannya. Maka pendidikan selalu diperlukan dan memerlukan suatu proses yang akan berlangsung terus menerus dalam usaha untuk mewariskan nilai-nilai dan kecakapan yang dimiliki oleh manusia pada generasi berikutnya.

Pendidikan diperlukan untuk membina dan memberikan bekal kepada generasi muda agar melanjutkan usaha-usaha yang telah dilaksanakan dalam menentukan aspekaspek individualisasi dan sosialisasi. Pendidikan agama Islam adalah bimbingan jasmani dan rohani berdasarkan hukum-hukum Islam menuju kepada terbentuknya kepribadian umat menurut ukuranukuran Islam. ${ }^{1}$ Pendidikan Islam adalah suatu usaha yang sistematis dan pragmatis dalam rangka mendidik anak didik yang beragama Islam dengan cara yang sedemikian rupa sehingga ajaran-

${ }^{1}$ Marimba, Ahmad D, 1989, Pengantar Filsafat Pendidikan Islam, Bandung, Al Ma'arif. h. 233 ajaran agama Islam itu dapat di pahami dan diyakini kebenarannya. ${ }^{2}$

Dari beberapa pendapat di atas dapat di pahami bahwa pendidikan agama Islam adalah suatu usaha yang dilakukan secara sistematis dan pragmatis yang diarahkan kepada anak didik dalam rangka menanamkan nilainilai ajaran agama Islam itu sendiri. Dengan demikian pendidikan agama Islam merupakan suatu proses yang terus-menerus. Oleh karena itu, guru merupakan salah satu unsur dibidang kependidikan harus berperan secara aktif dalam menempatkan kedudukannya sebagai tenaga profesional sesuai dengan tuntutan masyarakat yang semakin berkembang.

Pendidikan agama Islam merupakan salah satu mata pelajaran yang diajarkan disekolah menengah pertama. Di kalangan siswa terdapat kecenderungan, bahwa mata pelajaran ini kurang diminati. Karena mata pelajaran ini tidak termasuk mata pelajaran yang di-Ebtanaskan. Kurangnya minat siswa terhadap mata pelajaran ini, dimungkinkan karena kurangnya upaya guru untuk meningkatkan kreatifitas belajar siswa. Kebanyakan guru masih dominan menggunakan metode ceramah dalam mengajar sehingga tidak terciptanya

${ }^{2}$ Mahmud Yunus, 1979, Sejarah Pendidikan di Indonesia, Jakarta : Hida Karya Agung. h. 11 
proses pembelajaran yang menyenangkan dan bervariasi, yang dapat menambah semangat belajar siswa. Akibatnya, kegiatan belajar mengajar kurang menarik dan membosankan karena siswa tidak dirangsang atau ditantang untuk belajar dan berfikir kreatif.

Menurut Zakiah Darajat, (1995 : 263) pada dasarnya guru mempunyai tiga kompetensi yaitu kompetensi kepribadian, kompetensi penguasaan atas bahan dan kompetensi dalam caracara mengajar. Oleh karena itu tugas seorang guru pendidikan agama Islam adalah selain memberikan pengajaran juga memberikan pengetahuan keagamaan serta membina seluruh kemampuan yang dimiliki siswa dengan menambahkan dan meningkatkan keimanan atau ketakwaan siswa salah satunya pembinaan terhadap pelaksanaan ibadah shalat. ${ }^{3}$

Pembelajaran tentang shalat di dalam pendidikan formal sudah dimulai sejak di bangku Sekolah Dasar (SD), sehingga ketika berada di bangku Sekolah Menengah Pertama (SMP) sebenarnya shalat bukan hal yang baru dan asing bagi siswa. Namun demikian, dari hasil evaluasi melalui tes unjuk kerja terhadap siswa kelas 7 sebelum melakukan tindakan, menunjukkan bahwa sebagian besar siswa kelas 7 masih menunjukkan prestasi yang rendah dalam kemampuan melaksanakan shalat wajib terutama dalam kemampuan menghafal bacaanbacaan dalam shalat. Hal ini dapat terjadi karena tidak adanya proses pembelajaran yang tidak berkesinambungan pada awal pelajaran pada siswa kelas 7, disamping kurangnya pengamalan shalat wajib di rumah.

\footnotetext{
${ }^{3}$ Daradjat, Zakiah, 1995, Ilmu Fiqih Aid 1, Yogyakarta : Dana Bhakti wakaf. Hal 263
}

Oleh karena itu upaya untuk meningkatkan kemampuan menghafal bacaan-bacaan dalam shalat wajib bagi siswa kelas 7 di SMP Negeri 1 Banjar Margo Kabupaten Tulang Bawang, dengan cara melatih hafalan bacaanbacaan dalam shalat wajib secara berkesinambungan dengan menggunakan metode drill/latihan secara bersama-sama di setiap awal pelajaran agama Islam.

Pencerahan pembelajaran shalat wajib untuk anak tergantung pada profesionalisme guru serta metode yang digunakan. Untuk itu, guru dituntut memahami karakteristik anak didiknya dan memiliki ketrampilan khusus dalam mengajar sesuai dengan bidang keahliannya. Di antaranya adalah keterampilan dalam memilih materi dan menerapkan metode pembelajaran yang sesuai dengan karakter siswa, sehingga proses belajar mengajar dapat berjalan dalam situasi yang menarik dan menyenangkan. Dengan demikian, tanpa disadari anak diharapkan akan memperoleh apa yang menjadi tujuan dari pembelajaran tersebut. Di antara metode yang menarik dan menyenangkan bagi anakanak adalah metode drill / latihan, Karena itulah, Penelitian Tindakan Kelas ini dilaksanakan.

Penelitian ini dilaksanakan terkait dengan masih (a) rendahnya kemampuan siswa kelas VII pada kompetensi shalat wajib, (b) rendahnya motivasi siswa dalam praktik shalat wajib, (c) pentingnya penggunaan metode drill / latihan dalam pembelajaran, (d) kecocokan metode drill dengan usia anak kelas VII , (e) belum diterapkannya metode drill/latihan untuk pembelajaran agama Islam, (f) Metode drill/latihan sebagai media yang mudah dilakukan, 
(g) belum diadakannya penelitian tindakan kelas terkait dengan penerapan metode drill/latihan dalam materi ibadah shalat wajib.

Penerapan metode drill/ latihan pada kompetensi dasar mempraktekkan shalat wajib dalam proses pembelajaran ini diusulkan untuk diterapkan dalam rangka meningkatkan kebiasaan shalat wajib, khususnya pada aspek menghafal bacaan-bacaan shalat wajib dalam pembelajaran agama Islam di SMP Negeri 1 Banjar Margo, dengan harapan setelah diadakan penelitian ini seluruh siswa kelas VII mampu menghafal bacaan-bacaan shalat dan diamalkan dalam kehidupan seharihari.

maka $\begin{gathered}\text { Berdasarkan } \\ \text { penulis }\end{gathered}$ teraian tersebut, melaksanakan penelitian tindakan kelas dengan judul :"Peningkatan Kemampuan Menghafal Bacaanbacaan Shalat dengan Menggunakan Metode Drill di Awal Pelajaran pada Siswa kelas 7 Semester Ganjil SMP Negeri 1 Banjar Margo Kabupaten Tulang Bawang Tahun Pelajaran 2014/2015". Rumusan masalah dalam penelitian ini: apakah metode Drill yang dilakukan secara bersama-sama di awal setiap pelajaran Agama Islam dapat meningkatkan kemampuan siswa kelas 7 di SMP Negeri 1 Banjar Margo dalam menghafal bacaan-bacaan dalam shalat wajib?

Tujuan dalam penelitian ini untuk mengetahui apakah metode drill yang dilakukan secara bersama-sama di setiap awal pelajaran dapat meningkatkan kemampuan siswa kelas 7 SMP Negeri 1 Banjar Margo Kabupaten Tulang Bawang dalam menghafal bacaan-bacaan dalam shalat wajib.

\section{B. LANDASAN TEORI \\ 1. Kemampuan Menghafal Bacaan- Bacaan dalam Shalat}

Kegiatan shalat harus dibiasakan sejak dini, untuk mewujudkan pengamalan ibadah shalat maka diperlukan kesabaran, semangat, dan ketekunan yang tinggi dari guru pendidikan agama Islam dan senantiasa memberikan pembiasaan dalam pembinaan, bimbingan dan penyuluhan terhadap siswa sehingga dapat mendisiplinkan melaksanakan ibadah shalat dengan baik dan istiqomah.

Kata Shalat berasal dari bahasa Arab ash-shalah yang berarti doa. Menurut istilah syariat (hukum) Islam shalat berarti serangkaian ibadah yang berupa ucapan dan gerakan yang di mulai dengan takbiratul ihram dan di akhiri dengan salam dengan syarat dan rukun tertentu. Ketentuan wajibnya shalat lima waktu di sebutkan dalam QS. Al Baqarah ayat 43 :

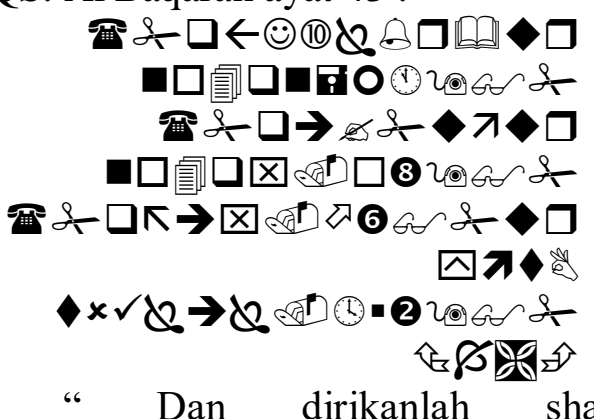

Dan dirikanlah shalat, tunaikanlah zakat dan ruku'lah beserta orang-orang yang ruku". (QS. Al Baqarah ayat 43). ${ }^{4}$

Berdasarkan ayat tersebut menunjukkan bahwa shalat adalah wajib ditunaikan oleh setiap orang Islam dengan memenuhi syarat dan rukunnya. dalam hal ini diharapkan anak didik mampu melaksanakan shalat wajib dengan kemampuan menghafal bacaan-bacaannya, memenuhi syarat dan rukunnya sebagaimana yang telah

${ }^{4}$ QS. Al Baqarah ayat 43 
diajarkan oleh guru pendidikan agama Islam.

Kemampuan Menghafal adalah Kemampuan untuk meresapkan ke dalam fikiran agar selalu ingat. Sedanngkan kata Bacaan dapat diartikan yang dibaca (diucapkan). ${ }^{5}$ Dalam konteks ibadah shalat bacaan yang harus diucapkan adalah berupa lafadz yaitu tulisan dalama Bahasa $\mathrm{Al}$ Qur'an atau Bahasa Arab.

Dari uraian di atas dapat disimpulkan bahwa "Kemampuan menghafal bacaan-bacaan dalam shalat wajib" mengandung arti "Kecakapan /keahlian di dalam mengucapkan lafadz-lafadz dalam shalat wajib tanpa melihat dari sumber yang ada". Shalat wajib adalah ibadah yang terdiri dari gerakan-gerakan dan bacaan-bacaan atau perkataan-perkataan mulai dari takbiratul ihram dan di akhiri dengan salam dengan memenuhi beberapa syarat yang ditentukan. ${ }^{6}$

\section{Metode Drill}

\section{Metode}

latihan

(drill)

merupakan model pembelajaran yang digunakan untuk memperoleh suatu ketangkasan atau keterampilan dari apa yang telah dipelajari. Dalam pembelajaran pendidikan agama Islam, materi yang bisa diajarkan dengan metode ini diantaranya adalah materi yang bersifat pembiasaan, seperti ibadah shalat, mengkafani jenazah, baca tulis Al quran dan lain-lain.

Belajar adalah proses di mana tingkah laku ditimbulkan atau diubah melalui praktek atau latihan. ${ }^{7}$ Oleh

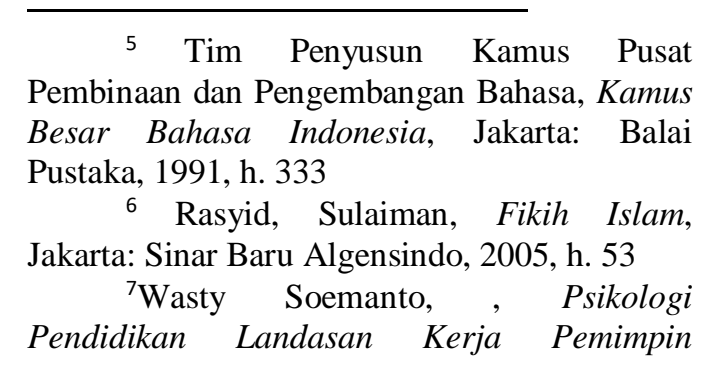

karena itu belajar perlu metode. Metode adalah cara yang digunakan untuk mengimplementasikan rencana yang sudah disusun dalam kegiatan nyata agar tujuan yang telah disusun tercapai secara optimal. Wina Sanjaya menyatakan bahwa metode dalam rangkaian sistem pembelajaran memegang peran yang sangat penting. Keberhasilan implementasi strategi pembelajaran sangat tergantung pada cara guru menggunakan metode pembelajaran. ${ }^{8}$

Metode drill atau latihan ialah suatu metode dalam pengajaran dengan jalan melatih anak-anak terhadap bahan pelajaran yang sudah diberikan. ${ }^{9}$ Arti "melatih" adalah mengajar seseorang agar terbiasa melakukan sesuatu. ${ }^{10}$ Proses pendidikan dan pembelajaran memerlukan latihan keterampilan, baik intelektual maupun motorik, sehingga menuntut guru untuk bertindak sebagai pelatih. Karena tanpa latihan seorang peserta didik tidak akan mampu menunjukkan penguasaan kompetensi dasar dan tidak akan mahir dalam berbagai keterampilan yang dikembangkan sesuai dengan materi materi standar. Oleh karena itu guru harus berperan sebagai pelatih, yang bertugas melatih peserta didik dalam pembentukan kompetensi dasar, sesuai dengan potensi masing-masing.

Pelatihan yang dilakukan di samping harus memperhatikan kompetensi dasar dan materi standar,

Pendidikan, Jakarta: Rineka Cipta, 2012, h. 104

${ }^{8}$ Wina Sanjaya, Strategi Pembelajaran Berorientasi Standar Proses Pendidikan, Jakarta: Kencana Prenada Media, 2006, h. 145

9 Zuhairini dkk, Metodik Khusus Pendidikan Agama Islam, Surabaya: Usaha Nasional, 1983, h. 106

10 Tim Penyusun Kamus Pusat Pembinaan dan Pengembangan Bahasa, Kamus Besar Bahasa Indonesia, Jakarta: Balai Pustaka, 1991, h. 569 
juga harus mampu memperhatikan perbedaan individual peserta didik dan lingkungannya, untuk itu guru harus banyak tahu meskipun tidak mencakup semua hal. ${ }^{11}$

Dengan latihan-latihan kita dapat mempertinggi kesanggupan memperoleh insight dalam situasisituasi yang bersamaan yang telah banyak dihadapi sebelumnya. ${ }^{12}$

Dari beberapa pendapat di atas dapat disimpulkan bahwa pengertian Metode Drill adalah metode pengajaran dengan cara membiasakan anak-anak untuk dapat memiliki kemampuan yang diharapkan baik berupa ucapan maupun perbuatan.

Secara umum pembelajaran dengan metode latihan (drill) biasanya digunakan agar siswa :

1) Memiliki

motoris/gerak,

kemampuan

menghafalkan kata-kata, menulis, dan mempergunakan alat.

2) Mengembangkan kecakapan intelek, seperti mengalikan, membagi, menjumlahkan

3) Memiliki kemampuan menghubungkan antara sesuatu keadaan dengan yang lain.

Beberapa keuntungan dalam pemanfaatan metode latihan adalah sebagai berikut :

1) Bahan pelajaran yang diberikan dalam suasana yang sungguhsungguh

2) akan lebih kokoh tertanam dalam daya ingatan siswa, karena seluruh pikiran, kemauan, perasaan dikonsentrasikan pada pelajaran yang dilatihkan.

$11 \quad{ }^{7}$ Mulyasa, E, Menjadi Guru Profesional, Menciptakan Pembelajaran Kreatif dan Menyenangkan, Bandung: Remaja Rosdakarya, 2015, h. 42- 43

12 Nasution, S, Didaktik Asas-asas Mengajar, Jakarta: Bumi Aksara, 2012, h. 42
3) Anak didik akan dapat mempergunakan daya pikirnya dengan bertambah

4) baik, karena dengan pengajaran yang baik maka anak didik akan menjadi lebih teratur, teliti dan mendorong daya ingatnya.

5) Adanya pengawasan, bimbingan dan koreksi yang segera serta langsung

6) dari guru, memungkinkan siswa untuk melakukan perbaikan kesalahan saat itu juga. Hal ini dapat menghemat waktu belajar disamping itu juga siswa langsung mengetahui prestasinya.

Di samping kelebihan yang dipunyai, juga ada beberapa kelemahan yang perlu mendapatkan perhatian yaitu ;

1) Latihan yang dilakukan di bawah pengawasan yang ketat dan suasana serius mudah sekali menimbulkan kebosanan.

2) Tekanan yang lebih berat yang diberikan setelah siswa merasa bosan atau jengkel tidak akan menambah gairah belajar dan menimbulkan keadaan psikis berupa mogok belajar/latihan.

3) Latihan yang terlampau berat menimbulkan perasaan benci dalam diri siswa, baik terhadap pelajaran maupun terhadap guru.

4) Latihan yang selalu di berikan di bawah bimbingan guru, perintah guru dapat melemahkan inisiatif maupun kreativitas siswa.

5) Karena tujuan latihan adalah untuk mengkokohkan asosiasi tertentu, maka siswa akan merasa asing terhadap semua struktur-struktur baru dan menimbulkan perasaan tidak berdaya.

Kelemahan-kelemahan di atas dapat di atasi dengan memperhatikan hal-hal berikut ini : 
1) Guru mengarahkan anak didik untuk memberikan respon yang maksimal dan reaksi yang tepat.

2) Jika terdapat kesulitan pada anak didik saat merespons, mereaksi, hendaknya guru segera meneliti sebab-sebab yang menimbulkan kesulitan tersebut.

3) Berikanlah segera penjelasanpenjelasan baik bagi reaksi atau respons yang maksimal dan reaksi yang tepat.

4) Usahakan siswa memiliki ketepatan merespon kemudian kecepatan merespon.

5) Istilah-istilah baik berupa kata-kata maupun kalimat-kalimat yang digunakan dalam latihan hendaknya dimengerti oleh anak didik.

\section{Langkah-langkah Latihan (Drill)}

Metode

Dalam pelaksanaannya, metode latihan (drill) terkadang mengalami beberapa hambatan, terutama yang terkait dengan kesiapan gurudan pengkondisian kelas. Dalam pelaksanaan metode drill ini tak kalah pentingnya bagi seorang guru adalah memerhatikan petunjuk dibawah ini :

1. Sebelum latihan dimulai, siswa hendaknya diberi pengertian yang mendalam tentang apa yang dilatihkan.

2. Latihan untuk pertama kalinya hendaknya bersifat diagnostis. Kalau pada latihan pertama siswa tidak berhasil, maka guru mengadakan perbaikan, lalu penyempurnaan.

3. Latihan tidak perlu lama asal sering dilaksanakan.

4. Latihan hendaknya disesuaikan dengan taraf kemampuan siswa.

5. Latihan hendaknya mendahulukan hal-hal yang esensial dan berguna.
Dalam pembelajaran dengan metode latihan paling tidak diperlukan syarat-syarat sebagai berikut :

1. Masa latihan harus menarik dan menyenangkan.

a. Agar hasil latihan memuaskan, minat instrinsik diperlukan

b. Tiap-tiap langkah kemajuan yang dicapai harus jelas.

c. Hasil latihan terbaik yang sedikit menggunakan emosi.

2. Latihan-latihan hanyalah untuk keterampilan tindakan yang bersifat otomatik.

3. Latihan diberikan dengan memperhitungkan kemampuan/daya tahan siswa, baik segi kejiwaan maupun jasmani.

4. Adanya pengarahan dan koreksi dari guru yang melatih sehingga siswa tidak perlu mengulang suatu respons yang salah.

5. Latihan diberikan secara sistematis.

6. Latihan lebih baik diberikan kepada perorangan karena memudahkan pengarahan dan koreksi.

7. Latihan-latihan harus diberikan terpisah menurut bidang ilmunya. ${ }^{13}$ Jadi dapat di simpulkan bahwa langkah-langkah penggunaan metode drill bersifat fleksibel, diserahkan kepada guru yang bersangkutan, disesuaikan dengan materi, waktu dan daya dukung yang ada. Metode ini dapat digunakan secara individu, kelompok atau bersama.

Dengan demikian Metode Drill/Latihan Ulang sangat tepat dan efektif untuk meningkatkan kemampuan menghafal bacaan-bacaan dalam shalat. Metode Drill /Latihan biasanya digunakan pada pelajarapelajaran yang bersifat motoris dan pelajaran-pelajaran yang bersifat

13 Ahmad Munjih Nasih, Metode dan Teknik Pembelajaran Pendidikan Agama Islam, Bandung: Refika Aditama, 2013, h. 9394 
kecakapan mental dalam arti melatih anak-anak berfikir cepat. ${ }^{14}$

Berdasarkan uraian dan analisis sebagaimana terdapat dalam uraian tersebut di atas, dapat dikemukakan beberapa catatan penting sebagai berikut:

Pertama, metode pengajaran sangat memegang peranan penting dalam mendukung keberhasilan pengajaran dan pendidikan. Pengajaran tampak lebih terkait dengan pemberian wawasan kognitif kepada peserta didik, yang selanjutnya dapat menimbulkan pengertian yang mendukung penghayatan dan pengamalan secara lebih mantap.

\section{METODE PENELITIAN}

\section{Latar dan Subyek Penelitian}

a. Latar Penelitian

Penelitian dilakukan di Sekolah Menengah Pertama (SMP) Negeri 1 Banjar Margo Kabupaten Tulang Bawang. Kelas VII Semester Ganjil Tahun Pelajaran 2014/2015.

b. Subyek penelitian

Penelitian dilakukan pada siswa kelas 7 di SMP Negeri 1 Banjar Margo sejumlah 25 siswa.

Pemilihan latar dan subyek penelitian didasarkan pada pertimbangan peneliti sebagai berikut :

1) Peneliti adalah guru agama pada SMP Negeri 1 Banjar Margo, sehingga hal ini akan sangat membantu peneliti dalam melaksanakan tugas sebagai guru di sekolah yang bersangkutan.

2) Materi pelajaran tentang shalat terdapat pada silabus kelas 7 dan usia siswa kelas 7 termasuk

14 Zuhairini, Metodik Khusus Pendidikan Agama Islam, Surabaya: Usaha Nasional, 1983, h. 106 usia yang mendekati dan atau sudah memasuki usia baligh.sehingga menjadi kehawatiran peneliti apabila terdapat siswa kelas 7 yang masih belum dapat melaksanakan shalat dengan baik. Sedangkan alasan peneliti dalam menentukan subyek penelitian kelas 7 dimaksudkan karena dalam hal kemampuan shalat, berdasarkan penilaian unjuk kerja sebelum melakukan tindakan penelitian menunjukkan bahwa kelas 7 memiliki prosentase kemampuan lebih rendah dari kelas lainnya.

\section{Rancangan Penelitian}

Penelitian yang dipilih di sini adalah Penelitian Tindakan Kelas. Hal ini disebabkan peneliti adalah seorang guru Pendidikan Agama Islam yang di dalam proses pembelajaran shalat menemukan permasalahan dalam diri siswa yaitu kurangnya kemampuan menghafal bacaan-bacaan dalam shalat wajib, sehingga dengan melakukan penelitian tindakan kelas ini diharapkan akan dapat membantu siswa meningkatkan kemampuan menghafal bacaan-bacaan dalam shalat wajib.

\section{Jenis Penelitian}

Jenis penelitian yang digunakan dalam penelitian ini adalah jenis penelitian deskriptif kualitatif. Jenis penelitian deskriptif kualitatif adalah metode penelitian yang berusaha mendeskripsikan suatu gejala, kejadian yang terjadi pada saat sekarang dengan menyimpulkan permasalahan dari deduktif ke induktif dan sebaliknya. ${ }^{15}$

\footnotetext{
${ }^{15}$ Nana Sujana, Cara Belajar Siswa Aktif Dalam Proses Belajar Mengajar, Bandung: Sinar Baru, 1999, h. 64
} 
Dari pendapat di atas dapat disimpulakan bahwa penelitian ini mengambil masalah atau memusatkan perhatian pada masalah-masalah aktual yang terjadi pada saat penelitian ini dilaksanakan. Di dalam metode deskritiif kualitatif terkandung petunjuk tentang bagaimana cara melaksanakan penelitian, sehingga dapat menghasilkan sesuatu yang benar dan dapat dipertanggungjawabkan.

\section{Prosedur Pelaksanaan Tindakan dan Pengamatan}

Prosedur pelaksanan penelitian tindakan ini terdiri dari 2 siklus, di mana kedua siklus tersebut saling terkait, artinya pelaksanaan siklus 2 merupakan kelanjutan dan perbaikan dari pelaksanaan siklus I.

\section{a. Siklus I}

\section{1) Rencana Tindakan}

Pada siklus I dibuat rencana kegiatan sebagai berikut :membuat rencana pelaksanaan penggunaan metode drill di setiap awal pelajaran, membuat instrumen pengumpulan data penelitian dan menyusun lembar observasi serta menyusun jadwal pelaksanaan tindakan.

2) Pelaksanaan Tindakan

Sebelum peneliti menjelaskan langkah-langkah pelaksanaan tindakan, ada beberapa hal yang dijelaskan di sini yaitu :

a) Mengingat waktu yang disediakan untuk melaksanakan tindakan ini sedikit yaitu sekitar 10 menit disetiap awal pelajaran, maka cara menghafal siswa adalah dengan menirukan guru yang mendemomstrasikan bacaan secara fasih. Hal ini dimungkinkan karena bacaanbacaan dalam shalat adalah materi yang tidak asing bagi siswa karena sejak di bangku
SD siswa sudah mulai diadakan pembelajaran.

b) Bacaan-bacaan shalat wajib yang harus dihafalkan oleh siswa

\section{3) Observasi}

Di dalam observasi peneliti mengadakan pengamatan untuk mengetahui hasil yang diperoleh dari siswa yaitu sejauhmana peningkatan yang dicapai siswa dengan mengngunakan metode drill di setiap awal pelajaran agama.

\section{4) Refleksi}

Setelah

diadakan evaluasi,observasi dan analisa data,maka selanjutnya peneliti melakukan refleksi yaitu perenungan terhadap hasil analisa data dengan melihat kembali proses tindakan yang telah dilakukan. Melalui refleksi ini akan ditetapkan apakah tindakan perlu ditindak lanjuti dengan tindakan siklus II atau tindakan ditetapkan sudah menghasilkan penyelesaian terhadap masalah yang ada,sehingga penelitian di anggap berakhir.

\section{b. Siklus II}

Pada siklus II peneliti merencanakan tindakan untuk melanjutkan program siklus I dengan menambahkan tindakan menunjuk salah seorang siswa untuk memimpin dan memberi contoh bacaan secara bergantian. Pelaksanaan tindakan pada siklus II hampir sama dengan pelaksanaan tindakan pada siklus I .Perbedaan hanya terletak pada pemberi contoh bacaan.Pada siklus I, pemberi contoh bacaan terpusat hanya kepada guru. sedangkan pada siklus II, pemimpin dan pemberi contoh bacaan diserahkan kepada siswa secara bergantian, supaya lebih menarik dan menambah motivasi untuk lebih 
menguasai

bacaan-bacaan

shalat.

\section{1) Teknik Pengumpulan data}

Teknik yang digunakan untuk pengambilan data dalam penelitian ini adalah dengan menggunakan tes unjuk kerja baik pada saat pra siklus atau sebelum pelaksanaan tindakan maupun setelah selesai tindakan. Sebelum pelaksanaan tindakan, peneliti mengadakan tes unjuk kerja untuk melihat kemampuann siswa dalam menghafal bacaan-bacaan shalat yang dilaksanakan di semester I, di mana pada semester I kelas 7 memang terdapat materi shalat. Dari hasil data yang diperoleh, maka peneliti melakukan analisa, dan dari hasil analisa data, peneliti melanjutkan dengan melakukan tindakan siklus I.

Setelah diadakan tindakan siklus I, peneliti mengadakan tes yang sama dengan tes yang dilakukan pada saat pra siklus yaitu tes unjuk kerja untuk mengetahui perubahan yang terjadi pada siswa dalam kemampuan menghafal bacaan-bacaan shalat wajib. Demikian juga pada saat selesai pelaksanaan tindakan siklus II, peneliti kembali mengumpulkan data siswa dengan menggunakan teknik tes/penilaian unjuk kerja.

\section{2) Teknik Analisis Data}

Analisis data adalah proses mengorganisasikan dan mengurutkan data ke dalam pola, kategori, dan satuan uraian dasar sehingga dapat ditemukan tema dan dapat dirumuskan hipotesis kerja seperti yang disarankan oleh data. ${ }^{16}$ Dari pendapat di atas dapat dikatakan bahwa Analisa data adalah proses pengolahan data, sehingga dirumuskan suatu hipotesis atau anggapan dasar dari penelitian yang dilakukan. Hal ini juga

16 Lexy J. Moleong, Metodologi Penelitian Kualitatif, Bandung: Remaja Rosdakarya, 2000, h. 103 menggambarkan bahwa analisis data merupakan hal yang sangat penting dalam suatu penelitian.

\section{HASIL PENELITIAN \\ 1. Deskripsi Hasil Penelitian} a. Temuan Studi Awal

Studi awal ini dimaksudkan untuk mempermudah siswa kelas 7 dalam menghafal bacaan-bacaan dalam shalat wajib yang termasuk kompetensi dasar dalam silabus kelas 7 Sekolah Menengah Pertama. Dengan kegiatan ini masalah yang dihadapi siswa berkaitan dengan menghafal bacaan-bacaan dalam shalat wajib dapat dideskripsikan dan selanjutnya dapat dipakai sebagai acuan untuk melaksanakan penelitian tindakan kelas.

Berdasarkan data studi awal yang diperoleh dari hasil tes unjuk kerja pada siswa dapat disajikan data nilai siswa kelas 7 tentang hafalan bacaan-bacaan dalam shalat wajib.

Tabel.

\section{Daftar nilai unjuk kerja hafalan bacaan-bacaan shalat wajib prasiklus}

\begin{tabular}{|c|c|c|c|c|c|}
\hline \multirow{2}{*}{ No. } & \multirow{2}{*}{$\mathrm{N}$ a m a } & \multirow{2}{*}{$\begin{array}{l}\mathrm{Jm} \\
1 \\
\mathrm{Sk} \\
\text { or }\end{array}$} & \multirow{2}{*}{ Nilai } & \multicolumn{2}{|c|}{$\begin{array}{l}\text { Keberhas } \\
\text { ilan }\end{array}$} \\
\hline & & & & $\mathrm{Ya}$ & $\begin{array}{l}\mathrm{Td} \\
\mathrm{k}\end{array}$ \\
\hline 1 & Ana Wulandari & 35 & 97.2 & & \\
\hline 2 & Anjar Wati & 33 & 91.6 & & \\
\hline 3 & Asa Nugrahani & 16 & 44.4 & & \\
\hline 4 & Ayu Nurul Syafitri & 5 & 13.9 & & \\
\hline 5 & Diah Sri Pinangsih & 5 & 13.9 & & \\
\hline 6 & Dwi Kurniawati & 34 & 94.4 & & \\
\hline 7 & Fajar Arlana & 34 & 94.4 & & \\
\hline 8 & Galang Efendi & 20 & 55.6 & & \\
\hline 9 & HelmaRahma Jairia & 19 & 52.7 & & \\
\hline 10 & Lisa Susanti & 16 & 44.4 & & \\
\hline 11 & M. Ilham Paresi & 25 & 69.4 & & \\
\hline 12 & Marlia Vermitha & 20 & 55.6 & & \\
\hline 13 & Mey Damayanti & 19 & 52.8 & & \\
\hline 14 & M. Tabri Laksana & 22 & 61.1 & & \\
\hline 15 & Nita Yuliyanti & 23 & 63.9 & & \\
\hline 16 & Nur Dafa Ariya H. & 30 & 83.3 & & \\
\hline 17 & Putri Benita Aprilia & 32 & 88.9 & & \\
\hline 18 & Richania Irawan & 30 & 83.3 & & \\
\hline 19 & Rido Aksa & 16 & 44.4 & & \\
\hline 20 & Sintia Fitriani & 18 & 50.0 & & \\
\hline 21 & Valent Trias M. & 17 & 47.2 & & \\
\hline
\end{tabular}




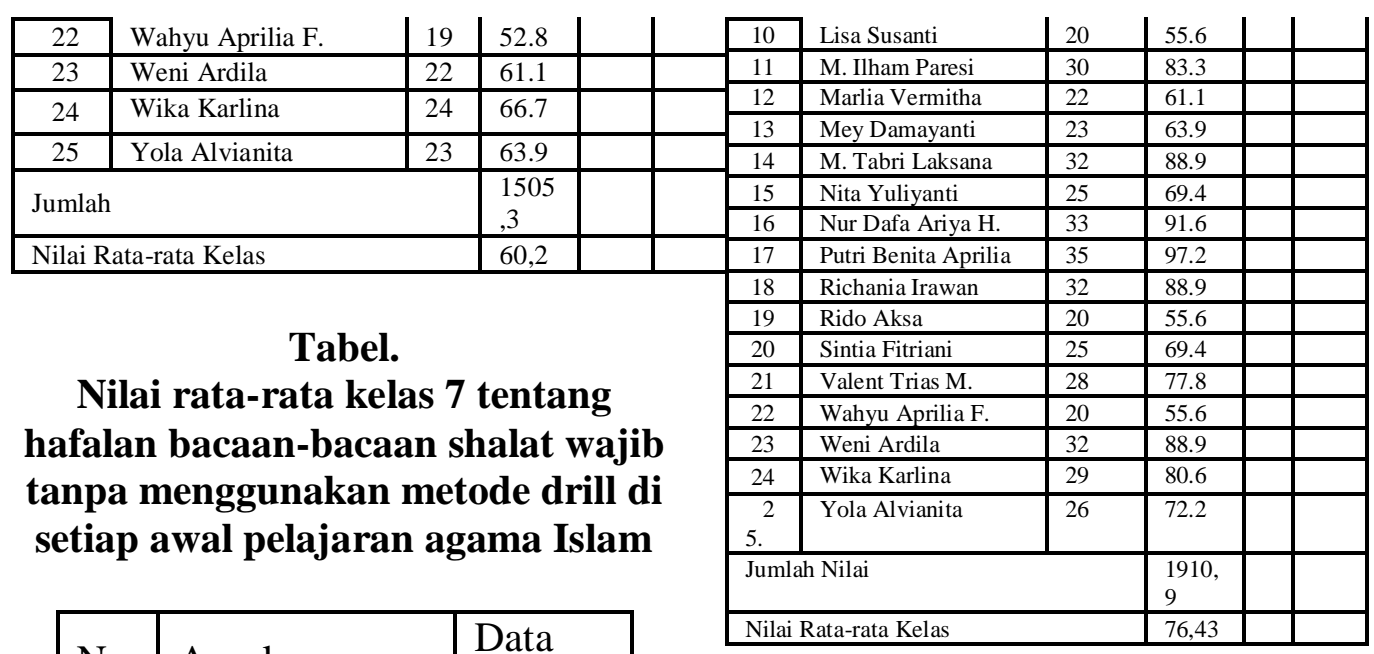

Tabel.

Nilai rata-rata kelas tentang hafalan bacaan-bacaan shalat wajib setelah menggunakan metode drill di setiap awal pelajaran agama Islam pada siklus I

\begin{tabular}{|l|l|l|l|}
\hline No. & Aspek & $\begin{array}{l}\text { Data } \\
\text { Awal }\end{array}$ & iklus I \\
\hline 1. & $\begin{array}{l}\text { Rata-rata } \\
\text { kelas }\end{array}$ & 60,2 & 76,43 \\
\hline 2 & $\begin{array}{l}\text { Siswa yang } \\
\text { berhasil }\end{array}$ & 7 & 14 \\
\hline 3. & $\begin{array}{l}\text { Persentase } \\
\text { keberhasilan }\end{array}$ & $28 \%$ & $56 \%$ \\
\hline
\end{tabular}

Sumber Data: Daftar nilai unjuk kerja tentang hafalan bacaan-bacaan shalat wajib pada kelas 7 siklus I

Berdasarkan data di atas, maka

\section{Siklus I}

Dari hasil pelaksanaan tindakan pada siklus I, maka diperoleh data nilai rata-rata kelas sebagai berikut :

Tabel.

\section{Daftar Nilai Unjuk Kerja Tentang Hafalan Bacaan-Bacaan Shalat Wajib Siklus I}

\begin{tabular}{|l|l|l|l|l|l|}
\hline \multirow{2}{*}{ No } & \multirow{2}{*}{ N a m a } & \multirow{2}{*}{$\begin{array}{l}\text { Jml } \\
\text { skr }\end{array}$} & Nilai & \multicolumn{2}{|c|}{$\begin{array}{l}\text { Keberha } \\
\text { silan }\end{array}$} \\
\cline { 5 - 7 } & & & $\begin{array}{l}\text { Y } \\
\mathrm{a}\end{array}$ & $\begin{array}{l}\text { Td } \\
\mathrm{k}\end{array}$ \\
\hline 1 & Ana Wulandari & 35 & 97.2 & & \\
\hline 2 & Anjar Wati & 35 & 97.2 & & \\
\hline 3 & Asa Nugrahani & 20 & 55.6 & & \\
\hline 4 & Ayu Nurul Syafitri & 22 & 61.1 & & \\
\hline 5 & Diah Sri Pinangsih & 19 & 52.7 & & \\
\hline 6 & Dwi Kurniawati & 35 & 97.2 & & \\
\hline 7 & Fajar Arlana & 35 & 97.2 & & \\
\hline 8 & Galang Efendi & 25 & 69.4 & & \\
\hline 9 & Helma Rahma Jairia & 30 & 83.3 & & \\
\hline
\end{tabular}

dapat diketahui bahwa kemampuan siswa tentang hafalan bacaan-bacaan shalat wajib adalah sebagai berikut :

1. Ada peningkatan prestasi siswa dalam menghafal bacaan-bacaan shalat wajib dari data awal yang menunjukkan rata-rata 60,2 menjadi 76,43. Hal ini menunjukkan adanya kenaikan nilai rata-rata sebesar 16,23.

2. Ada kenaikan jumlah siswa yang berhasil menghafal bacaan-bacaan shalat wajib dengan nilai di atas 70,00 sebanyak 14 siswa dari sebelumnya yang hanya berjumlah 7 siswa. Hal ini menunjukkan adanya kenaikan jumlah siswa yang 
berhasil sebanyak 7 siswa.

3. Ada peningkatan nilai rata-rata kelas dan jumlah siswa yang berhasil, maka dapat disimpulkan adanya peningkatan persentase keberhasilan.Dalam hal ini persentase keberhasilan meningkat $28 \%$ (dari data awal $28 \%$ menjadi $56 \%$ pada siklus I).

\section{Siklus II}

Pada siklus II ini diadakan perbaikan dalam tindakan yaitu menjadikan siswa sebagai model pembelajaran yang mendemonstrasikan bacaan dan memimpin dalam menghafal secara bersama-sama dengan cara bergantian.

Adapun hasil pelaksanaan tindakan siklus ini dapat dilihat pada table berikut :

Tabel.

Daftar Nilai Unjuk Kerja Tentang

Hafalan Bacaan- Bacaan Shalat Wajib Siklus II

\begin{tabular}{|l|l|l|l|l|l|}
\hline \multirow{2}{*}{ NO } & \multirow{2}{*}{ N A M A } & \multirow{2}{*}{$\begin{array}{l}\text { Nml } \\
\text { Skr }\end{array}$} & I & \multicolumn{2}{|l|}{$\begin{array}{l}\text { KEBERHA } \\
\text { SILAN }\end{array}$} \\
\hline & & & & Ya & Tdk \\
\hline 1 & Ana Wulandari & 36 & 100 & & \\
\hline 2 & Anjar Wati & 35 & 97.2 & & \\
\hline 3 & Asa Nugrahani & 27 & 75 & & \\
\hline 4 & Ayu Nurul Syafitri & 28 & 77.8 & & \\
\hline 5 & Diah Sri Pinangsih & 27 & 75 & & \\
\hline 6 & Dwi Kurniawati & 35 & 97.2 & & \\
\hline 7 & Fajar Arlana & 36 & 100 & & \\
\hline 8 & Galang Efendi & 30 & 83.3 & & \\
\hline 9 & Helma Rahma Jairia & 32 & 88.9 & & \\
\hline 10 & Lisa Susanti & 27 & 75 & & \\
\hline 11 & M. Ilham Paresi & 29 & 80.6 & & \\
\hline 12 & Marlia Vermitha & 27 & 75 & & \\
\hline 13 & Mey Damayanti & 28 & 77.8 & & \\
\hline 14 & M. Tabri Laksana & 34 & 94.4 & & \\
\hline 15 & Nita Yuliyanti & 30 & 83.3 & & \\
\hline 16 & Nur Dafa Ariya H. & 35 & 97.2 & & \\
\hline 17 & Putri Benita Aprilia & 35 & 97.2 & & \\
\hline 18 & Richania Irawan & 33 & 91.7 & & \\
\hline 19 & Rido Aksa & 27 & 75 & & \\
\hline 20 & Sintia Fitriani & 29 & 80.6 & & \\
\hline 21 & Valent Trias M. & 31 & 86.1 & & \\
\hline 22 & Wahyu Aprilia F. & 28 & 77.8 & & \\
\hline 23 & Weni Ardila & 33 & 91.7 & & \\
\hline 24 & Wika Karlina & 32 & 83.3 & & \\
\hline 25 & Yola Alvianita & 30 & 83.3 & & \\
\hline Jumlah Nilai & & 2144, & & \\
\hline & & & 85.77 & & \\
\hline Nilai Rata-rata Kelas & & & & \\
\hline & & & & \\
\hline
\end{tabular}

Tabel.
Nilai rata-rata kelas tentang hafalan bacaan-bacaan shalat wajib setelah menggunakan metode drill di setiap awal pelajaran agama Islam pada siklus II

\begin{tabular}{|l|l|l|l|}
\hline No. & \multicolumn{1}{|c|}{ Aspek } & \multicolumn{1}{|c|}{ Siklus I } & \multicolumn{1}{c|}{$\begin{array}{c}\text { Siklus } \\
\text { II }\end{array}$} \\
\hline 1. & Rata-rata kelas & 76,43 & 85,77 \\
\hline 2 & $\begin{array}{l}\text { Siswa yang } \\
\text { berhasil }\end{array}$ & 14 & 25 \\
\hline 3. & $\begin{array}{l}\text { Persentase } \\
\text { keberhasilan }\end{array}$ & $56 \%$ & $100 \%$ \\
\hline
\end{tabular}

Sumber Data : Daftar nilai unjuk kerja tentang hafalan bacaan-bacaan shalat wajib siklus II

Dari data di atas dapat dilaporkan hasil sebagai berikut :

1. Terdapat kenaikan nilai rata-rata kelas sebesar 9,35 dari siklus I yang menunjukkan rata-rata 76,43 menjadi 85,77 pada siklus II

2. Seluruh siswa ( 25 siswa ) mendapat nilai di atas atau sama dengan 70,00. Hal ini menunjukkan adanya peningkatan jumlah siswa yang berhasil sebanyak 25 siswa.

3. Persentase keberhasilan siswa mencapai $100 \%$. Ini menunjukkan terjadinya peningkatan sebesar 44 $\%$ dari data hasil siklus I

\section{Perbandingan Hasil Studi awal} dengan Hasil Siklus I dan II .

Perbandingan hasil studi awal dengan hasil siklus I dan siklus II merupakan suatu analisis untuk mengetahui perkembangan kemampuan yang dicapai siswa dalam menghafal bacaan-bacaan shalat wajib. Adapun data tentang perbandingan yang dimaksud dapat dilihat pada tabel di bawah ini :

\section{Tabel}

\section{Data Perbandingan nilai rata-rata} kelas pada data awal, siklus I dan Siklus II

\begin{tabular}{|l|l|l|l|l|}
\hline No & Apek & $\begin{array}{l}\text { Data } \\
\text { awal }\end{array}$ & Siklus I & $\begin{array}{l}\text { Siklus } \\
\text { II }\end{array}$ \\
\hline
\end{tabular}




\begin{tabular}{|l|l|l|l|l|}
\hline 1. & $\begin{array}{l}\text { Rata-rata } \\
\text { Kelas }\end{array}$ & 60,2 & 76,43 & 85.77 \\
\hline 2. & $\begin{array}{l}\text { Siswa yang } \\
\text { berhasil }\end{array}$ & 7 & 14 & 25 \\
\hline 3. & $\begin{array}{l}\text { Persentase } \\
\text { Keberhasilan }\end{array}$ & $\begin{array}{l}28 \\
\%\end{array}$ & $56 \%$ & $\begin{array}{l}100 \\
\%\end{array}$ \\
\hline
\end{tabular}

Sumber Data : Daftar nilai unjuk kerja tentang hafalan bacaan-bacaan shalat wajib perbandingan nilai rata-rata kelas pada data awal, siklus I dan siklus II. Dari data di atas maka dapat dilihat perbandingan dari hasil studi awal, tindakan siklus I dan siklus II sebagai berikut :

1. Terdapat peningkatan kemampuan atau prestasi belajar yang cukup tinggi. Berdasarkan data dari temuan awal ke siklus I dan siklus II selalu mengalami peningkatan nilai.

2. Dengan diterapkannya metode drill di awal setiap pelajaran agama Islam, maka terdapat peningkatan rata-rata kelas dari sebelum nya yaitu 60,2 menjadi 76,43. Sedangkan dari siklus I ke siklus II terjadi peningkatan nilai rata-rata kelas sebesar 85,77. Hal ini menunjukkan adanya peningkatan persentase keberhasilan dari temuan awal ke siklus II sebesar 72 $\%$.

3. Kenaikan nilai dari siklus I ke siklus II tersebut merupakan akibat dari penambahan tindakan berupa mengambil model pembelajaran untuk mendemonstrasikan dan memimpin dalam menghafal bersama secara bergantian.

\section{E. ANALISIS DATA}

Dari data-data yang diperoleh mulai dari studi awal atau sebelum diterapkan metode drill di setiap awal pelajaran agama Islam sampai diadakannya penelitian tindakan yang terdiri dari siklus I dan siklus II, maka dapat diuraikan hasil analisa sebagai berikut :
1. Untuk meningkatkan hafalan siswa pada bacaan-bacaan shalat wajib sangat diperlukan proses pembiasaan atau metode yang mengarah pada pembentukan kebiasaan yaitu dengan menggunakan metode drill.Hal ini dapat dibuktikan dari data yang diperoleh dari kelas 7 SMP Negeri 1 Banjar Margo Kabupaten Tulang Bawang, yang menunjukkan adanya peningkatan yang signifikan setelah diterapkan metode drill secara bersama-sama dalam menghafal bacaan-bacaan shalat wajib yaitu dengan peningkatan sebesar $72 \%$.

2. Penggunaan metode drill akan lebih hidup dan bermakna bagi siswa apabila dalam pelaksanaannya melibatkan siswa sebagai sentral dan guru hanya sebagai fasilitator. Hal ini terbukti dari data yang didapat, dimana pada siklus I yang masih menempatkan guru sebagai sentral dan siswa hanya menirukan didapat peningkatan sebesar $28 \%$ sedangkan pada siklus II dengan menjadikan siswa sebagai sentral dan guru hanya sebagai fasilitator di dapat peningkatan yang lebih tinggi yaitu sebesar $56 \%$.

\section{F. KESIMPULAN}

Dari hasil penelitian ini dapat disimpulkan bahwa kemampuan menghafal bacaan-bacaan dalam shalat wajib pada siswa SMP Negeri 1 Banjar Margo sesuai dengan rumusan masalah dan tujuan penelitian ini adalah sebagai berikut :

1. Kemampuan menghafal bacaanbacaan shalat wajib pada siswa SMP Negeri 1 Banjar Margo tanpa didukung dengan penerapan metode drill di setiap awal pelajaran Agama Islam secara 
bersama-sama masih sangat rendah atau dibawah standar minimal prestasi yang diharapkan, di mana nilai rata-rata kelas hanya sebesar 60,2 dan persentase keberhasilan hanya mencapai $28 \%$.

2. Kemampuan menghafal bacaanbacaan shalat wajib pada siswa SMP Negeri 1 Banjar Margo kelas 7 dapat meningkat dengan diterapkannya metode drill di setiap awal pelajaran agama Islam dengan peningkatan nilai rata-rata kelas sebesar 16,23 ( dari rata-rata kelas 60,2 menjadi 76,43 pada siklus II ) Sedangkan peningkatan persentase keberhasilan mencapai $44 \%$ ( dari persentase keberhasilan sebesar 56 $\%$ menjadi $100 \%$ pada siklus II ).

3. Kemampuan menghafal bacaanbacaan shalat wajib pada siswa SMP Negeri 1 Banjar Margo kelas 7 akan menunjukkan hasil yang lebih baik apabila penerapan metode drill di setiap awal pelajaran agama Islam lebih banyak melibatkan siswa dan guru hanya sebagai fasilitator yaitu dengan peningkatan nilai rata-rata kelas sebesar 9,34 ( dari nilai ratarata kelas sebesar 76,43 pada siklus I menjadi 85.77 pada siklus II ). Sedangkan peningkatan persentase keberhasilan mencapai $44 \%$ ( dari siklus I mencapai $56 \%$ menjadi $100 \%$ pada siklus II ).

\section{G. SARAN-SARAN.}

Saran-saran dalam penelitian ini ditujukan kepada :

1. Guru agar selalu berupaya untuk meningkatkan hasil belajar siswa dengan berbagai metode dan strategi pengajaran yang bervariasi dan relevan termasuk pengajaran dalam pelajaran agama.
2. Kepala sekolah agar lebih meningkatkan dukungan dalam pengembangan dan peningkatan kemampuan beragama pada anak didik atau siswa dalam bentuk selalu mendukung kegiatan keagamaan baik yang diselenggarakan di dalam dan di luar sekolah termasuk pengiriman siswa dalam lomba-lomba yang diselenggarakan oleh instansi tekait.

\section{DAFTAR PUSTAKA}

Daradjat, Zakiah, Ilmu Fiqih Aid 1, Yogyakarta : Dana Bhakti wakaf, 1995

Jexy J. Moleong, Metodologi Penelitian Kualitatif, Bandung : Remaja, 2000

Rosdakarya.

Mahmud Yunus, Sejarah Pendidikan di Indonesia, Jakarta : Hida Karya

Agung, 1979

Marimba, Ahmad D, Pengantar Filsafat Pendidikan Islam, Bandung, Al Ma'arif, 1989

Mulyasa, E., Menjadi Guru Profesional, Menciptakan Pembelajaran Kreatif dan Menyenangkan, Bandung : Remaja Rosdakarya, 2015

Nasih, Ahmad Munjih, Metode dan Teknik Pembelajaran Pendidikan

Agama Islam, Bandung : Refika Aditama. 2013

Rasyid, Sulaiman., Fiqh Islam, Jakarta : Sinar Baru Algensindo, 2005

Sudjana, Nana., Cara Belajar Siswa Aktif dalam Proses Belajar Mengajar, 1989 
Tim Penyusun Kamus Pusat Pembinaan dan Pengembangan Bahasa, Kamus Besar Bahasa Indonesia, Jakarta : Balai Pustaka, 1991

Wina Sanjaya, Strategi Pembelajaran Berorientasi Standar Proses Pendidikan, Jakarta : Kencana Prenada Media, 2006

Wasty Soemanto, Psikologi Pendidikan Landasan Kerja Pemimpin Pendidikan, Jakarta : Rineka Cipta, 2012

Zakiah Daradjat, Metodik Khusus Pengajaran Agama Islam, Jakarta : Bumi Aksara, 1995 